\title{
PPROACHING THE PAST: A TANGLED INTERPLAY OF MEMORY, POLITICAL 1 CHOICES AND HISTORICAL SCIENCE. WITH EXAMPLES FROM THE NORDIC AND BALTIC COUNTRIES AND ROMANIA
}

\section{Jardar Seim}

The Norwegian Historical Association, E-mail: jardar.seim@online.no

\section{Acknowledgements}

This paper was presented at the Sixth international conference on Baltic and Nordic Studies in Romania, Historical memory, the politics of memory and cultural identity: Romania, Scandinavia and the Baltic Sea Region in comparison, organized by the Romanian Association for Baltic and Nordic Studies, Faculty of History and Political Sciences of Ovidius University of Constanța and International Summer School of The University of Oslo, Norway, May 22-23, 2015. Supported by a grant from Iceland, Liechtenstein and Norway, The EEA Fund for Bilateral Relations, contract no. 910/20.03.2015.

\begin{abstract}
:
A discussion of topics connected with "historical memory" and "politics of memory" presupposes that we consider how and why we are approaching the past. In this paper I shall point to some ways the past is being approached by individuals, social groups and political authorities - and some reasons for such approaches. But I shall also consider the opposite choice, that of not wanting to get closer to the past, preferring instead to keep a safe distance or even to ignore it, at least painful parts of it. Memories in different forms are important in our approaches to the past. The same is true for scientific history. The interplay between memory and historical science is complicated in itself. The existence of political guidance or explicit political provisions concerning the past makes it even more complicated to understand how our relations with the past are shaped and what their functions are in a given society. In my opinion, it is impossible to generalize about such problems. But comparisons may be fruitful, for instance presentations of wars in school textbooks from different countries, or how succeeding political regimes in one country try to charge the urban landscape with a new (or old) political meaning that legitimizes the present regime or demonize another one, by changing street names, erecting or destroying monuments etc. National anthems are another field that is
\end{abstract}


suited for meaningful comparisons. And even communal or personal memories that are studied without a comparison or generalization in mind may provide ideas and perspectives for dealing with quite different memories under other political conditions. Finally, the role of the presumed scientific historian ought to be examined a little. Is he or she just a rational and neutral judge of the past compared to ordinary people with undocumented and emotional memories, or to politicians with ideological motives for approaching the past?

\section{Rezumat:}

O discutie referitoare la subiecte legate de "memoria istorică" şi "politicile memoriei" presupune luarea în considerare a cum şi de ce abordăm trecutul. In această lucrare voi arăta câteva modalităti în care trecutul este abordat de persoane, grupuri sociale şi autorități politice - şi câteva motive pentru astfel de abordări. Dar voi lua în considerare şi varianta contrară, aceea de a nu dori apropierea de trecut, preferând $\hat{i}$ schimb păstrarea unei distanțe de siguranță, sau chiar ignorarea acestuia, cel putin a unor momente dureroase ale lui. Memoriile în diferite forme sunt importante în abordările noastre vizavi de trecut. Acelaşi lucru este valabil pentru istoria ştiințifică. Interacțiunea dintre memorie şi ştiința istorică este complicată în sine. Existența unei îndrumări politice sau a unor prevederi politice explicite referitoare la trecut face şi mai complicată îțelegerea modului $\hat{\imath}$ care sunt modelate relațile noastre $\mathrm{cu}$ trecutul şi a funcțiilor lor într-o anumită societate. In opinia mea, este imposibilă generalizarea unor astfel de probleme. Dar comparațiile pot fi prolifice, de pildă prezentarea războaielor în manualele şcolare din diverse țări sau a modului în care regimurile politice succesive dintr-o țară încearcă să schimbe peisajul urban cu un îțeles politic nou (sau vechi), care legitimează regimul actual sau demonizează un altul, prin schimbarea numelor de străzi, ridicarea sau distrugerea de monumente etc. Imnurile nationale sunt un alt domeniu potrivit pentru comparatii semnificative. Chiar memorii colective sau personale care sunt studiate fără a avea în minte o comparație sau o generalizare pot furniza idei şi perspective pentru a trata memorii destul de diferite $\hat{i n}$ alte circumstanțe politice. In cele din urmă, ar trebui să fie examinat puțin rolul presupusului istoric ştiințific. Este el sau ea doar un judecător rațional şi neutru al trecutului - comparat cu oamenii obişnuiți cu amintiri nedocumentate şi emoționale sau cu politicienii cu rațiuni ideologice de abordare a trecutului?

Keywords: Scandinavia; Romania; Baltic countries; memory; history; comparison

Speaking in Constanța about the topic "Approaching the past" may also contain a personal element related to this city. My first visit here took place 50 years ago, in August 1965. I was then a student participating at the 
international summer course for foreign students and teachers in Sinaia. Regarding the Romanian language I was a beginner. After three weeks in Sinaia we were taken on an excursion first to Transylvania, then to the Black Sea, staying in Mamaia and visiting Constanța and other points of interest, like Istria and Adamclisi. Not many specific memories stand out from those few days here. But I remember that one day I exchanged some stuttering words in Romanian with somebody in the street, receiving encouraging nods from one of the teachers from the Sinaia course. I even remember his name, Boris Cazacu. And I remember my first visit ever to a mosque, the more than 100 years old edifice constructed at the initiative of the Romanian state. ${ }^{1}$ In 1965 I happened to be in Constanța on August 23, the first National Day after the election of Nicolae Ceauşescu as secretary general of the Communist party earlier that year. In particular I can visualize a counter for presenting fruits and vegetables at the market; the different colors of the fruits and vegetables being used to generate the words "Trăiască 23 August", long live 23 August. In the following years Constanța came to be known in Norway as the nearest city to the summer holiday resort Mamaia. A friend of mine told me that he had spent eight summers at that coastline from 1968 onwards as a tour leader for more or less crazy Norwegian young people. Regardless of how some of the young Norwegians behaved, he made many Romanian friends. Norwegian friends have also shared other early memories from Constanța. One of them had participated in 1971 in an international light athletics contest between Norway and Romania in Constanța. Romania won the match. ${ }^{2}$ At that time he sported a red beard, so at the departure a customs officer recognized him from the match and simply called him Barbarossa and let him through without further formalities. He hadn't won any of the competitions, but his red beard singled him out from all the other participants and made him sort of a celebrity. That became his most outstanding memory from Constanța. Another friend of mine with old memories from Constanța was a sailor on a Norwegian cargo ship visiting the port. When I once met him he cryptically murmured something about the Western sailors' open eyes in Communist ports in the early Cold War

\footnotetext{
${ }_{1}^{1}$ A construction begun in 1910. The first religious service was held in 1913 in the presence of King Carol I. For a time the mosque was even called The Carol I Mosque. http:/ / stiri.tvr.ro/constanta-marea-moschee-un-secol-de-existenta-in-6-iunie-1913-se-oficiaprimul-serviciu-religios_31331.html (retrieved 15.05.2015).

2 Aftenposten, Oslo 12.05.1971.
} 
years. The next time we talked he knew nothing of that sort. No wonder that he told me of very strict conditions for sailors having a shore leave. He added that the conditions in China (Shanghai) were even stricter. Before that, in the interwar years, the frequency of Norwegian ships in the harbor of Constanța was so considerable that The Norwegian Seamen's Mission established a station (a reading room, not a real church), in Constanța. It was inaugurated almost exactly 80 years ago, on the Norwegian National Day, May 17, 1935.3 An additional reason for this initiative was that nowhere else in the world did the oil tankers have so long laytime as in Constanța. Or so it was said in Norway as an argument to start some activity there, I haven't checked the facts about the laytime. There were many temptations for young Norwegians (many of the sailors were actually quite young at that time) in the thriving night life of Constanța. Many sailors visited the station. But from 1937 the traffic of Norwegian oil tankers diminished considerably, and after a while the station was closed. The property was lost by war and revolutionary measures. ${ }^{4}$ But the house is still there.

These memories, strictly personal or through friends of mine, might be used to illustrate some important aspects of the history of Constanța and Romania. But only if enough additional knowledge is established by other means. Then these memories might serve as illustrations in a more representative way - or judged as exceptions to a rule. In a single person's memory, however, they may constitute the main picture of a country and a port city. So here we are in the middle of our topic, ways of approaching the past.

I would like to make a start on that topic by a quotation from the Bible. In general the Bible is full of references to historical phenomena, and there is a clear timeline and a specific Jewish calendar. But in the Gospel of Luke we find the following statement of Jesus (9:62): "No one who puts his hand to the plow and looks back is fit for the Kingdom of God." If he looks back while plowing, the furrow will be crooked. It is a question of concentrating on what is an important job. I think that this way of thinking may be appropriated by many revolutionaries, people that want to create a

\footnotetext{
3 The keynote speech was delivered on May 22, 2015.

4 http://sjomannskirken.no/historien/kirke/constantza (retrieved

Earlier version: http://www.sjomannskirken.no/hoved.aspx?m=2187

09.11.2009) 
radically different future for the society, in defiance of the many obliquities of the factual world rooted in the past. Romania experienced in the last century two types of such aspirations, the Iron Guard and the Communist Party.

Many political revolutionaries that acquire power soon discover, however, that forgetting about the past may be a good idea and useful for their purpose, but quite unrealistic. To be a normal human being simply implies consciousness about the past. To solve this dilemma dictators and other authoritarian forces normally do their best - and worst - to control the people's conception of the past. It was succinctly expressed by George Orwell in his novel 1984:

O'Brien was looking down at him speculatively. More than ever he had the air of a teacher taking pains with a wayward but promising child.

'There is a Party slogan dealing with the control of the past,' he said. 'Repeat it, if you please.'

'"Who controls the past controls the future: who controls the present controls the past,"' repeated Winston obediently. ${ }^{5}$

If the message of this scene had been a claim that individuals in general strive to retain true memories of the past against distortions made by others, it would have been a bit flawed. The people's memories are in themselves often painful and in some cases combined with shame and a feeling of guilt. It may be tempting to hide them away. They can be mentally repressed. Another situation arises when memories disappear from the daily consciousness, not because they are painful, but because of a mental illness.

For several years I was a coordinator for a student exchange between a Norwegian and a Romanian upper secondary school. The Norwegian students had social sciences among their school subjects. Returning home they had to write individual reports about their experiences, trying to make use of some elementary insights from sociology and political science when describing and sorting out their impressions. All students stayed for a week in a private family that had a child of the same age, dividing their time between a common program for all (or in small

5 Part III, Chapter III. 
groups and workshops), and time with the host family. In 1996 the memories of the Romanian revolution were still alive for young people and visible as bullet holes - in Braşov. One of the reports contained the following passage:

\begin{abstract}
"In Brașov I could observe some traces of the revolution in 1989. I saw buildings with bullet holes. My host student told me a little about the revolution. She and her family had a quite difficult time then. Her father had a job for the party and was taken prisoner. He was to be killed, but managed to escape. The whole family had to hide. This was a very traumatic experience for my host, so she was reluctant to speak of the revolution."
\end{abstract}

This could provide a starting point for a historian who wanted to write about some aspects of the revolution in Brașov. He or she might then try to get some more testimonies, assessing their value as sources and their representativeness, making good use of the rich content of the toolbox of a professional historian. The evaluated material could be used for discussing several problems with changing points of view. It could be with a political focus - the struggle for power is central if one speaks of a revolution (and should it really be called a revolution?), it could be treated more as social history, or gender history, or urban history turning the attention to local geographical differences. So there are plenty of possibilities making use of the historian's traditional methods and tools in combination with the broader repertoire in history writing thanks to the development of historiography in modern time.

Even if $\mathrm{I}$ in this example started out from a second hand testimony about the revolutionary days in Brașov in 1989, methodologies for how to use different memories to establish a more general historical narrative or analysis is not the central point in our discussion of memory and history today. One modern definition of memory reads as follows: "The electronic holding place for instructions and data that your computer's microprocessor can reach quickly."6 But in our context we are more interested in human memory as a faculty of retaining and recalling past experience, and something that is remembered from the past. History can be interpreted as what happened in the past, or the narration of what

\footnotetext{
6 This definition may be found in many places, for instance http:// whatis.techtarget.com/search/query?q=Memory (retrieved 15.05.2015).
} 
happened in the past, or the scientific study of what happened in the past. Memory is more loaded with subjectivity, history with objectivity. Memory has therefore been associated with imprecision and distortion of a former reality. Scientific history on the other hand has a stronger appearance of objectivity. But that appearance may be quite deceptive. For instance, the number of footnotes and archival references cannot compensate for women being left out (or being almost left out) from traditional national histories, or peasants and agricultural workers being left out from a history of agriculture. But the subjectivity of the historian's perspective and the selection of themes is much better camouflaged than when we speak of memories.

The relationship between memory and history has seen many twists and turns. If in the remote past memory was the main gateway to the past, and presented to others mainly orally, later on the writing of history took the lead. And the writing of history very often meant adapting it to the organization of societies in national states, making political history the most important force. But there were also dissenting voices. Marxist historians wanted for instance to uncover the real forces that determined the historical development. All who have learnt history in a communist society know how the interesting idea of taking a closer look at the material forces to understand how a society changed, rapidly degenerated into a scheme that can be compared to one-size clothes - it had to fit all sorts of different bodies - and societies. At the same time the belief that there could only be one true history was quite common across the whole ideological range.

That also holds true for one of the pioneers of thinking about memory and history, the French sociologist Maurice Halbwachs (18771945). He was very interested in memory as a way of approaching the past, but he drew a distinct line between memory and history. Simplified he said that "history is unitary, there is only one history. But there are many memories."7 What made Halbwachs original in the 1920s, however, was the idea of collective memories. ${ }^{8}$ There are not only individual memories, but

\footnotetext{
${ }^{7}$ Cited from Bill Niven and Stefan Berger, "The relationship between history and memory", in Writing the History of Memory, ed. by Stefan Berger and Bill Niven (Bloomsbury 2014), 2.

8 For a short introduction: Mary Fulbrook, "History-writing and 'collective memory" , in Writing the History of Memory, ed. by Stefan Berger and Bill Niven (Bloomsbury 2014), 65-88. For a larger overview: Jeffrey Olick, Vered Vinitzky-Seroussi and Daniel Levy (eds), The Collective Memory Reader (Oxford 2011).
} 
group memories. That means that the way an individual understands the past is not only a combination of the personal memories and what he or she learnt in school. The understanding of the past is also linked to a group consciousness that is over-individual, but at the same time different from what the state may have defined as normal knowledge and assessment of the past for a national citizen, for instance through the school curriculum or the military service. That way of thinking has later worked in a fruitful way for many historians. The central question in relation to memories is then not necessarily how factual they are, how they correspond to a real past. The interesting thing is what collective memories can tell about how people understand the past - and why they do it in one particular way over another.

In this perspective the occurrence of what the Germans call Ostalgie is relevant. Ostalgie is a sort of nostalgia for some aspects of life in East Germany, often connected with culture and brand marks from daily life. ${ }^{9}$ It exists in other former Communist countries as well, and may also be related to some social advantages for workers that were lost in the transition.

It is of course possible that in the beginning this way of thinking may have been influenced by former party functionaries who wanted to sow the seeds of dissatisfaction with the new regimes in the 1990s. But I think it deserves to be mentioned here as an example of collective memories, and it also demonstrates how present-day experiences may change the perception of the past.

In many other cases it is clear that political authorities want to influence how the population look upon the past. That may be because a certain understanding of the past can give the present rulers a greater legitimacy. The actual rulers can be seen as successors of somebody prestigious, or they can interpret the past in a way that underlines former national losses of territory or blames the loss of real or pretended greatness on disloyal ethnic minorities - in order to be seen as defenders of national values that are threatened today. Europe in the twentieth century is full of examples of this, including Ceaușescu and Romania as well as Yugoslavia and Milošević in the last decades of the twentieth century. This approach may be typical for authoritarian leaders, but may also be a temptation for

\footnotetext{
9 Daphne Berdahl, "(N)Ostalgie for the Present: Memory, Longing, and East German Things". Ethnos, 64:2 (1999), 192-211.
} 
presumably democratic leaders that perhaps are in danger of losing an election. The hired consultants we find in a modern, democratic election campaign are often adept at the type of collective memories that can be mobilized in the population, and make use of that knowledge.

When a country experiences a sudden change of its political system, like the establishment or the fall of communism in Eastern Europe, or when a region after a war suddenly becomes part of another country, the new rulers may want to remove visible evidence in the urban landscape of the former regime and its ways of approaching the past. Typically a great number of street names will be changed ${ }^{10}$ and a lot of statues taken down leaving behind them numerous empty plinths. The plinths can be removed, or something else can be put there. As a rule there will be simple political explanations for the changes. But in Lithuania one of the Lenin statues that disappeared was replaced by a new statue that had no direct link with the liberation of the country from the enforced membership in the Union of Socialist Soviet Republics. The American rock legend Frank Zappa took Lenin's place. That was not an initiative of the new anti-communist authorities; it was a rather private initiative that surprisingly enough succeeded. One of the initiators, Saulius Paukstys, commented on it in this way: "We were desperate to find a symbol that would mark the end of communism, but at the same time express that it wasn't always doom and gloom. At first the authorities criticized the plan, particularly after discovering that Zappa was a bit of a leftie. They said: What has he got to do with Lithuania anyway? We said: Nothing really. Then someone convinced them that Zappa had Jewish features and seeing as Jewish history is very important for Lithuania, they plumped for that." 11

I don't know what happened to that particular Lenin statue. But when I once visited Kraków, I also made a trip by a wonderful tramway to Nowa Huta, the industrial town constructed in the communist period on the outskirts of Kraków. Poland's largest steel mill was located there, and of course it was named after Lenin. Nowa Huta is interesting from many points of view, including the original socialist architecture that was clearly

\footnotetext{
10 For a discussion of renaming of streets as a means of "decommemorating" a former political regime, see: Duncan Light, Ion Nicolae and Bogdan Suditu, "Toponymy and the Communist city: Street names in Bucharest, 1948-1965“. GeoJournal, 56:2 (2002), 135-144.

11 The Guardian 29.01.2000, http://www.theguardian.com/travel/2000/jan/29/lithuania (retrieved 20.04.2015).
} 
formed to express certain social ideas ${ }^{12}$ - and thus becoming part of the collective memory, and including the special history of the construction of the large and beautiful Roman Catholic Church called the Lord's Ark13, consecrated in 1977 by Bishop Karol Wojtyła, the future Pope John Paul II. The steel mill is still there, but the size is much reduced. The Central Square ${ }^{14}$, originally named after Stalin, was in 2004 renamed Ronald Reagan Square. ${ }^{15}$ And the giant statue of Lenin is now to be seen in a Wild West theme amusement park in Sweden called High Chaparral. ${ }^{1617}$

Another example of a statue that has found a new home is from Norway. In a way it is not correct to speak of a new home, since the statue was homeless most of its life. I am talking about what was supposed to be the most important national monument in Norway. Thoughts about the need for such a monument had been launched in the Norwegian parliament as early as 1836. After several rounds, a well known and respected sculptor won the competition in 1925 with a project consisting of a high column inspired by Roman triumphal columns; Trajan's triumphal column in Rome commemorating emperor Trajan's victory in the Dacian wars in present-day Romania could be mentioned here. Among the other competitors was Gustav Vigeland, the author of the Vigeland Park in Oslo. The column of the winning project should have reliefs with motives from

\footnotetext{
12 For an introduction, see the architecture chapter on the Nowa Huta website www.nh.pl: http://english.nh.pl/architecture.htm (retrieved 15.05.2015).

13 http:/ / cracow.travel/guide-to-krakow/let-s-visit/nowa-huta/action,get,id,2732,t,Ark-ofLord-Church.html (retrieved 15.05.2015).

14 Plac Centralny. For a short introduction: http://english.nh.pl/plac.htm (retrieved 15.05.2015).

15 There were many protests against the renaming (for instance: Should "Central Square" really be considered a communist name?), and a certain compromise was found by establishing the official name as "Plac Centralny im. Ronalda Reagana". But by visiting Nowa Huta in 2007 I could observe that the road sign had much larger letters for the three last words than for the two first words in the official name.

16 https://en.wikipedia.org/wiki/High_Chaparral_Theme_Park (retrieved 15.05.2015). Although the amusement park is a Wild West theme park, it has several oddities far from the theme, the Lenin statue being one of them. But Lenin is not mentioned on the official website of the park, http://www.highchaparral.se/en/ (as of 15.05.2015).

17 In Nowa Huta (Pittsburgh 2014) Kinga Pozniak discusses the development of Nowa Huta from the beginning (1949) through the first Communist decades and the later Solidarity period up until nowadays. Through interviewing of residents of three generations she shows the formation of different collective memories and the use of history for specific political purposes. Both the renaming of the Central Square in 2004 and the destiny of the Lenin statue from its erection in 1973 through the Solidarity years until it was taken down in 1989 and eventually sold to Sweden, are discussed in the book.
} 
the Norwegian history. In 1935 the Parliament decided that the column should be erected. But in the economic hard times of the 1930s the project was temporarily stopped in 1939. In the Second World War, when Norway was occupied by Nazi Germany, and Quisling and the Norwegian Nazis governed under German supremacy, the project was reopened. No Norwegian authorities were as eager to use national symbols from the past as the puppet government of Quisling. But they did not have enough time to finish the project, and after the war the whole thing came to a standstill. But no formal decision was taken about the future of the monument. Finally, the Parliament took a decision in 1972. The monument should not be erected. Part of the explanation was that this way of portraying a nation was not in accordance with the postwar artistic and cultural taste. But the main explanation was that the sculptor, Wilhelm Rasmussen ${ }^{18}$, had been a dedicated member of Quisling's political party since 1933, the founding year of the party. Not everybody agreed that the process should be stopped; the artist had after all won the competition before he joined the party. But nevertheless the majority felt that it would be impossible to have a national monument made by a Nazi, who was even convicted after the war. So what happened with the monument? Something similar to the Lenin statue from Nowa Huta. A private citizen, a hotel owner called Åsmund Elvesæter, used more than two million Norwegian crowns to erect the column outside his hotel in a valley in the middle of Norway in 1992. A real surprise for tourists driving through the valley in their cars. One could imagine that he was a former Nazi or with Nazi sympathies in his family. He was not. He had taken part in the resistance movement during the war and had been imprisoned by the Germans. But he liked the monument and thought its decay was a shame. Moreover, he had known the artist when he had visited his hotel after the war. ${ }^{19}$

The Polish and Norwegian monuments were meant to express a political view in the public space, a manifestation of something worthy to be remembered as an inspiration for the future. Looking back in order to plow better, in contrast to what I quoted from the Bible earlier. They were intended to be sites or realms of memory, to use an English translation of

18 https://nbl.snl.no/Wilhelm_Rasmussen (retrieved 15.05.2015), from Norsk biografisk leksikon, vol. 7, 2003.

19 Dagbladet - Magasinet (web edition), published 05.12.2006, http://www.dagbladet.no/magasinet/2006/12/05/484991.html (retrieved 15.05.2015). See also: Arvid Møller, Søyle i skyggeland. Billedhuggeren Wilhelm Rasmussen (Oslo 1996). 
the French term lieux de mémoire, a concept coined by the French historian Pierre Nora in his seven-volume collaborative work Les lieux de mémoire (Paris 1984-92)20. But both monuments ended as curiosities, the Polish one because the motif belonged to a former and dictatorial regime, the Norwegian one because the artist was associated with a former and dictatorial regime.

At the present time there seems to be a great interest in memories. Sometimes one can even feel that it is more important to study what is remembered and how the memories are used, than studying what actually happened. At the same time one must be aware that memories, individual as well as collective memories, are much more than memories of what happened as actions or events. A particular smell typical of an industrial town or of a special food eaten in childhood may immediately awake memories if it is encountered under different circumstances many years later. The sight of a building where the secret police tortured people, may awake certain memories many years later even if the building now is used for very different purposes, and the person in question never had problems with the secret police. Memories are also mental associations and feelings attached to former states or conditions of life.

Scientific history will always try to find out what really happened in the past, even if it is impossible to think of a total and unitary history that can answer all questions. But it is also important to study how we approach the past through different sorts of memories, sometimes directed or strongly influenced by political authorities, but very often not. This tangled interplay between memory, political choices and historical science is fascinating as a realm of research.

20 For a short introduction: Benoît Majerus, "Lieux de mémoire - A European transfer story", in Writing the History of Memory, ed. by Stefan Berger and Bill Niven (Bloomsbury 2014), 157-171. 


\section{References:}

\section{Books and articles:}

Berdahl, Daphne. "(N)Ostalgie for the Present: Memory, Longing, and East German Things". Ethnos, 64:2 (1999): 192-211.

Fulbrook, Mary. "History-writing and 'collective memory"', in Writing the History of Memory. Ed. by Stefan Berger and Bill Niven. Bloomsbury 2014, 65-88.

Light, Duncan, Ion Nicolae and Bogdan Suditu. "Toponymy and the Communist city: Street names in Bucharest, 1948-1965“. GeoJournal, $56: 2$ (2002), 135-144.

Majerus, Benoît. "Lieux de mémoire - A European transfer story", in Writing the History of Memory. Ed. by Stefan Berger and Bill Niven. Bloomsbury 2014, 157-171.

Møller, Arvid. Søyle i skyggeland. Billedhuggeren Wilhelm Rasmussen. Oslo 1996.

Niven, Bill and Stefan Berger. "The relationship between history and memory“, in Writing the History of Memory, ed. by Stefan Berger and Bill Niven (Bloomsbury 2014), 2.

Nowa Huta website www.nh.pl: http://english.nh.pl/architecture.htm (retrieved 15.05.2015).

Olick, Jeffrey, Vered Vinitzky-Seroussi and Daniel Levy (eds). The Collective Memory Reader. Oxford 2011.

\section{Web postings and newspapers:}

Aftenposten, Oslo 12.05.1971.

Dagbladet - Magasinet (web edition), published 05.12.2006, http:/ / www.dagbladet.no/magasinet/2006/12/05/484991.html (retrieved 15.05.2015).

http:/ / cracow.travel/ guide-to-krakow/let-s-visit/nowa-

huta/action,get,id,2732,t,Ark-of-Lord-Church.html (retrieved 15.05.2015).

http:/ /english.nh.pl/plac.htm (retrieved 15.05.2015).

http:/ / sjomannskirken.no/historien/kirke/constantza 16.05.2015) 
http:/ / stiri.tvr.ro/constanta-marea-moschee-un-secol-de-existenta-in-6iunie-1913-se-oficia-primul-serviciu-religios_31331.html (retrieved 15.05.2015).

http:// whatis.techtarget.com/search/query?q=Memory (retrieved 15.05.2015).

http://www.highchaparral.se/en/ (as of 15.05.2015).

http:/ / www.sjomannskirken.no/hoved.aspx?m=2187

(retrieved 09.11.2009)

https://en.wikipedia.org/wiki/High_Chaparral_Theme_Park (retrieved 15.05.2015).

https://nbl.snl.no/Wilhelm_Rasmussen (retrieved 15.05.2015), from Norsk biografisk leksikon, vol. 7, 2003.

The

Guardian 29.01.2000, http://www.theguardian.com/travel/2000/jan/29/lithuania (retrieved 20.04.2015). 